\title{
The formation of the Hot Springs at Bath Spa, UK.
}

R. W. Gallois, 2007. Geological Magazine, Vol. 144, 741-747.

Abstract The hot springs that emerge at $46^{\circ} \mathrm{C}$ in the centre of Bath Spa, Somerset are unique in the UK. The four other thermal springs in Britain are also sourced in the Carboniferous Limestone, but they emerge at significantly lower temperatures $\left(20^{\circ}\right.$ to $\left.28^{\circ} \mathrm{C}\right)$. Bath is situated in a region of low geothermal gradient $\left(\mathrm{c} 20^{\circ} \mathrm{C} / \mathrm{km}\right.$ depth) in a geological setting that seems an unlikely place for hot springs. Why then are these the only hot springs in Britain, and why are they confined to such a small $(20 \times 80 \mathrm{~m})$ area? The explanation presented here involves a sequence of geological events involving Triassic dissolution and Pleistocene permafrost that is unique to central Bath.

92 Stoke Valley Rd., Exeter EX4 5ER, U.K.

E-mail: gallois@geologist.co.uk)

Keywords: Bath Spa, hot springs, hydrothermal, origin

\section{Introduction}

There are only five known occurrences of thermal springs in the UK, of which only that at Bath Spa exceeds the $30^{\circ} \mathrm{C}$ defined by White (1957) as the lowest temperature at which a spring should be called hot. The springs at Hotwells (Bristol), Taff's Well (Cardiff), and Buxton and Matlock Spa (Peak District) emerge at $20^{\circ}$ to $28^{\circ} \mathrm{C}$. All five thermal springs are sourced in the Carboniferous Limestone in similar geological settings. At each locality the geological structure allows meteoric water to descend to sufficient depth for it to be heated by the geothermal gradient, and return to the surface without a significant fall in temperature. A similar mechanism is present at numerous thermal springs in sedimentary basins elsewhere in the world. However, Bath Spa is situated in a geological setting that does not, at first sight, appear to differ markedly from parts of Britain where springs emerge from the Carboniferous Limestone and similar limestone aquifers at an ambient $10^{\circ}$ to $11^{\circ} \mathrm{C}$. The formation of the hot springs must therefore be dependent on a combination of geological circumstances that is unique to a small area beneath the centre of Bath Spa.

There are three hot springs at Bath, the King's, Cross Bath and Hetling springs, located within an area of about $20 \times 80 \mathrm{~m}$ in the oldest part of the city [ST 750 647]. In their natural state the springs would have bubbled up through river gravels in the 
floodplain of the River Avon. They were entrained by the Romans, possibly about the time of the Emperor Claudius (Cunliffe 1983), and have been in more or less continuous use for medicinal and recreational purposes since that time. Beneath much of Bath, the river deposits overlie almost horizontal late Triassic to early Jurassic sediments that rest with marked unconformity on folded Carboniferous rocks at relatively shallow depths, mostly 50 to $100 \mathrm{~m}$ below ground level along the river valley (Rastall 1926).

The chemistry of the thermal water is well documented (Andrews 1991; Darling \& Edmunds 2001; Edmunds \& Miles 1991) and has given rise to some widely agreed conclusions. Foremost among these are that almost all (>95\%) the water is meteoric in origin, is probably thousands rather than hundreds of years old, is in chemical equilibrium with the local Carboniferous Limestone, and has been heated to a maximum temperature of $64^{\circ}$ to $96^{\circ} \mathrm{C}$ (Edmunds 2004). There is no known igneous heat source in the area, and this is reflected in a low regional geothermal gradient of about $20^{\circ} \mathrm{C} / \mathrm{km}$ depth (Downing \& Gray 1986; Baker et al. 2000). This suggests that the hot-springs water has been geothermally heated at temperatures that require burial depths of at least 2500 m (Edmunds et al. 2002).

\section{Geological setting}

The springs lie on the eastern edge of a large synclinal basin in which the Carboniferous Limestone has a basinward-dipping catchment area of c $200 \mathrm{~km}^{2}$ and an estimated maximum volume of about $480 \mathrm{~km}^{3}$. In the central part of the basin, where the formation is overlain by Millstone Grit and thick Coal Measures, its top is at a depth of $>2500 \mathrm{~m}$ over an area of about $100 \mathrm{~km}^{2}$ (Fig. 1). The region was extensively deformed during the Variscan Orogeny with the result that there are numerous major thrusts and faults within the basin (Kellaway \& Welch, 1993). Many of the faults in the region were repeatedly reactivated throughout the Mesozoic, and deformation probably continued until the Miocene (Kellaway \& Welch 1948; Bevan \& Hancock 1986).

The most widely accepted hypothesis to explain the mechanism of the hot springs to date has been the Mendips Model (Andrews et al. 1982) in which the source of the springs is meteoric water falling on the Mendip Hills, 10 to $15 \mathrm{~km}$ south and south-west of Bath. The model (Fig. 2) fulfils the principal criteria for the development of hot springs in sedimentary basins. It includes a high-relief catchment area in which a reservoir rock (the 1000-m thick Carboniferous Limestone) crops out, a geological 
structure in which the limestone is carried down to sufficient depth for its contained groundwater to be geothermally heated to a high temperature, an overlying predominantly argillaceous succession that acts as an aquiclude, and a fracture zone that allows the heated water to rise rapidly to the surface. The difference in topographical height between the catchment area and the hot springs is presumed in the Mendips Model to explain why the springs emerge with an artesian head of up to $9 \mathrm{~m}$ above the natural ground level.

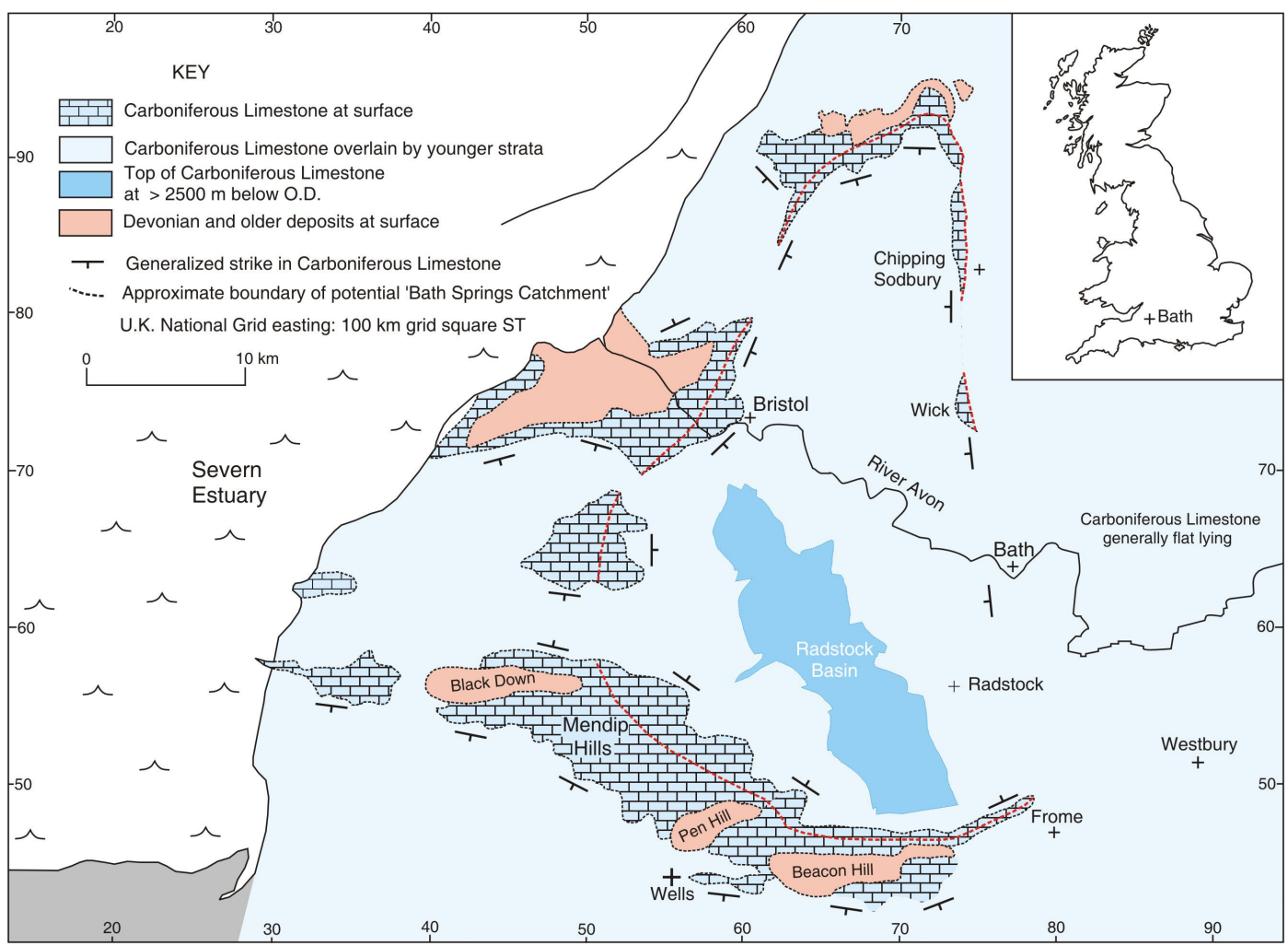

Figure 1. Presumed catchment area of the Bath hot springs (based largely on Kellaway \& Welch, 1993).

Extensive mining and associated exploration in the Radstock Coalfield and adjacent areas suggests that the tectonic complexity is such that the Carboniferous Limestone at outcrop in the Mendip Hills is unlikely to be in direct hydraulic continuity with that beneath Bath. However, the extent of the faulting and fracturing within the basin as a whole is such that there is no geological reason why, over a residence period of thousands of years, any part of the Carboniferous Limestone outcrop around its edges could not have contributed to the groundwater hosted in the formation in the deepest part of the basin. 
In an alternative to the Mendips Model, Kellaway (1996) suggested that the hot springs are located on an Avon-Solent Fracture Zone, a deep-seated NW-SE trending structure that crosses the Avon Valley at Bath, and that this was the conduit by which hot water escapes to the surface at the springs without significant heat loss. None of the local faults known from geological mapping and mining has been specifically linked to the hot springs, and seismic-reflection surveys carried out in the area adjacent to the springs did not detect any additional structures that might be related to them (McCann et al. 2002).

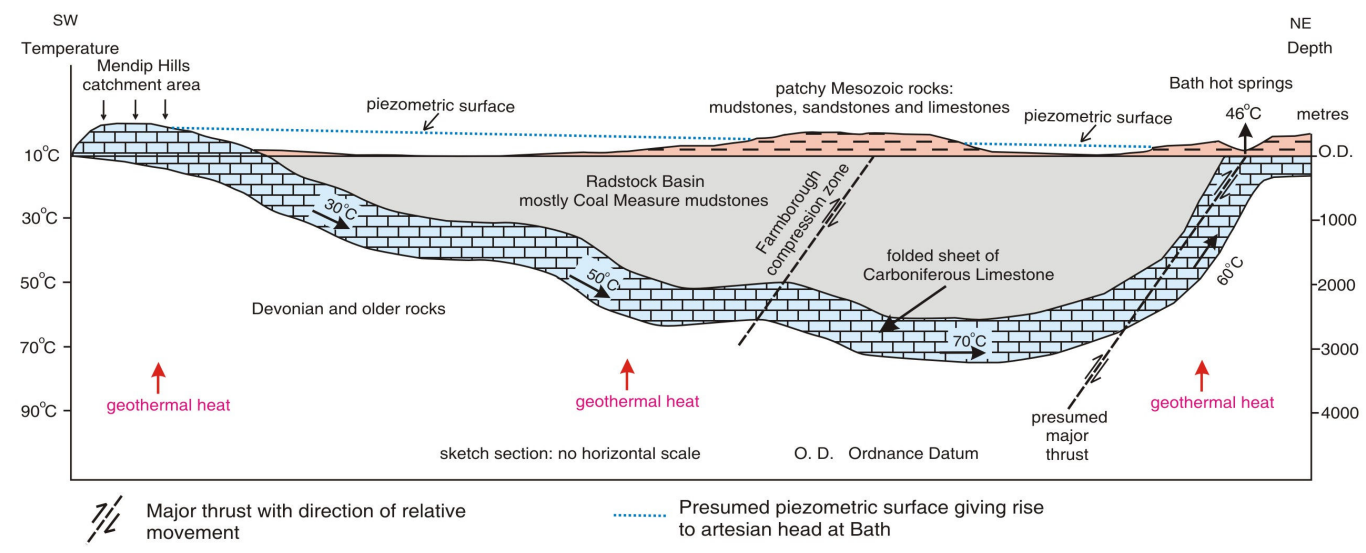

Figure 2. Geological sketch section between the Mendip Hills and Bath to illustrate the Mendips Model (based on Andrews et al., 1982).

There is, however, indirect evidence of a concentration of fracturing close to the hot springs. The only river gap in the 100-km long Cotswolds escarpment is at Bath where the River Avon appears to have taken advantage of more fractured strata. The river changes direction abruptly from a roughly NE-SW to an E-W course within 500m of the hot springs, suggesting a change in the trend of a fracture zone or an intersection of two zones in that area. Documentary evidence from pumping tests carried out in the $19^{\text {th }}$ century showed that there was a hydraulic link between a coal shaft at Batheaston [ST 782 675], $4 \mathrm{~km} \mathrm{NE}$ of Bath, and the hot springs (Warner, 1811), and that the river valley in that area is underlain by more permeable strata.

The combination of a suitable geological structure to generate geothermally heated water and possible fracture pathways to bring it to the surface without significant temperature loss is insufficient to explain the uniqueness of the Bath hot springs. On the west side of the basin, a thermal spring [ST 5652 7294] emerges from the Carboniferous 
Limestone in a fracture zone in the floor of the Avon Gorge at Hotwells, Bristol, but at a much lower temperature $\left(24^{\circ} \mathrm{C}\right)$ than that of the Bath springs (Hawkins \& Kellaway 1991). The lower temperature might be due to mixing with cool near-surface waters and/or to a shallower source. Similar explanations have been proposed for the thermal springs at Taff's Well (Squirrel \& Downing 1969) and in the Peak District (Downing \& Gray, 1986). Unlike those at Bath, the thermal springs at all four locations emerge from limestone outcrops that are not confined by an impermeable aquiclude.

The Carboniferous Limestone rises steeply to the surface or near surface on the eastern limb of the basin between Chipping Sodbury and Radstock, but hot water only emerges at Bath. For example, heavily fractured limestone is worked in deep quarries at Wick [ST 710 730], $9 \mathrm{~km} \mathrm{NW}$ of the hot springs, but the water pumped from them is at ambient temperatures. Many of the coal mines within the Bristol-Bath Basin, including that at Twerton $3 \mathrm{~km} \mathrm{~W}$ of the hot springs, encountered large quantities of cold groundwater in heavily fractured zones that are presumed to continue down to the Carboniferous Limestone (Kellaway \& Welch 1993).

\section{Dissolution features}

Neither the Mendips Model nor the Avon-Solent Fracture Zone theory explains why the hot springs at Bath are confined to such a small area. The key additional factor that favoured their development seems to have been the presence of palaeokarst in the Carboniferous Limestone. The deposition of the limestone was followed in the BathBristol region by a long period of sub-aqueous environments during which the Millstone Grit and Coal Measures were deposited. Uplift and erosion during the Variscan Orogeny locally removed these younger deposits and exposed the Carboniferous Limestone to subaerial erosion during the terrestrial environments of the Triassic Period. Solution pipes and cavities infilled or partially filled with loose, permeable debris are common in these areas (Benton \& Spencer 1994; Cave 1977). Beneath much of Bath, coarse-grained clastic Triassic rocks (Dolomitic Conglomerate) rest on an irregular former land surface cut in the Carboniferous Limestone. The hot springs emerge from a high point on this surface, from a small knoll of solution-affected limestone that is overlain by as little as $2 \mathrm{~m}$ of Triassic rocks (Fig. 3). Boreholes adjacent to the King's and Hetling springs proved open and debris-filled fissures and cavities in the highest part of the limestone (Kellaway 1991a; Stanton 1991). The area 
was planed off in the latest Triassic and subsequently buried beneath a thick succession of Triassic and Jurassic rocks that include several mudstone formations, notably the Westbury Formation and Lias Group, that are effective aquicludes.

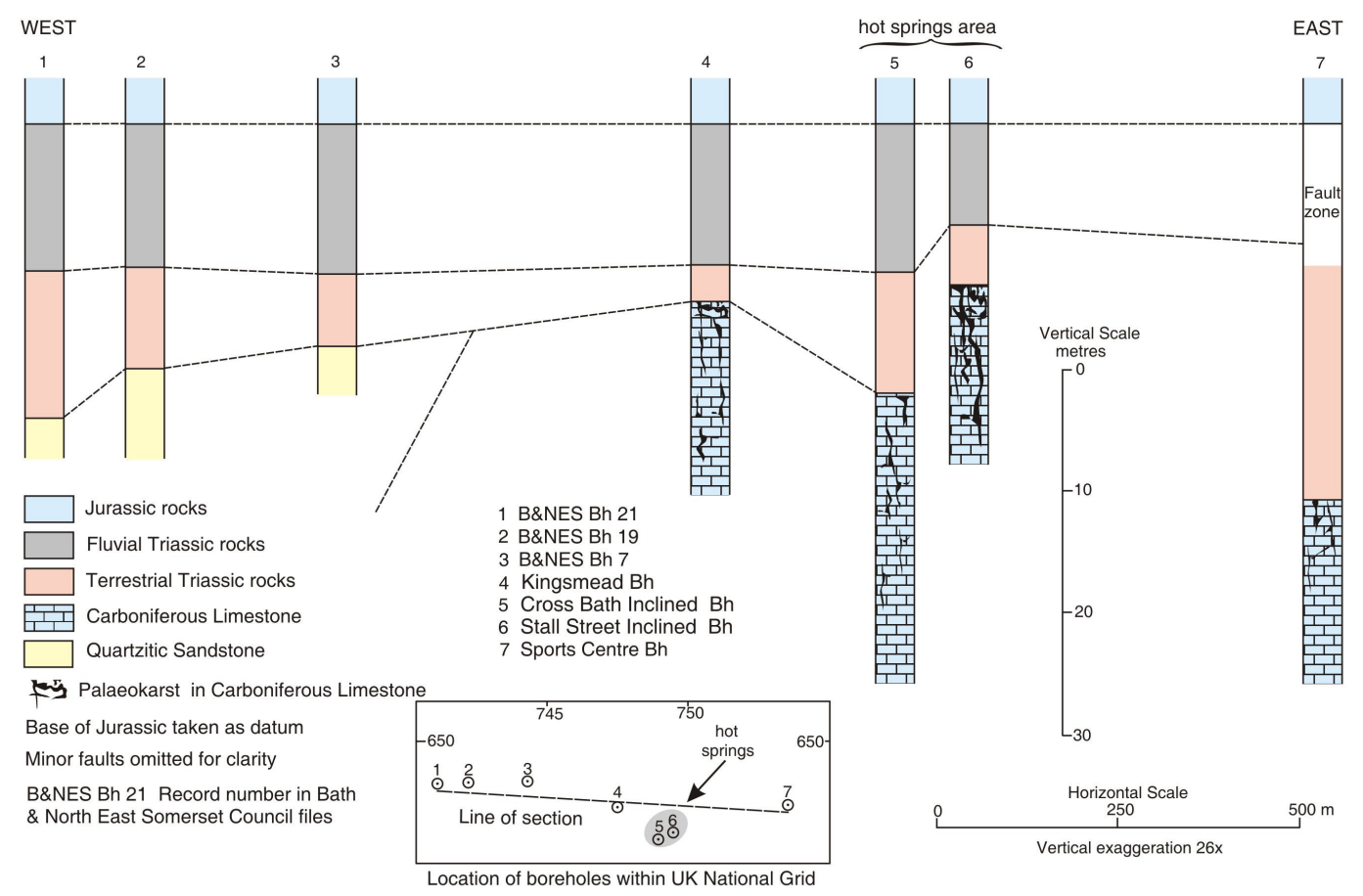

Figure 3. Geological section through the hot-springs area showing the late Triassic land surface. The Kingsmead Borehole yields hot water under artesian head and is hydraulically closely connected to the hot springs at depth. There is no historical record of a natural hot spring at this site.

Exploratory drilling through and beneath the King's and Cross Bath springs in the 1980s showed that the hot water reaches the surface via 'spring pipes', inverted conical structures up to $16 \mathrm{~m}$ across at the surface and up to $70 \mathrm{~m}$ deep infilled with loose river deposits and blocks of Triassic and Jurassic rocks (Kellaway 1991a). The pipes were originally presumed to have formed by hydraulic fracturing under the artesian head of the hot springs which caused the water to 'drill up' through the overlying rocks (Kellaway 1991b). However, the pressures exerted by the artesian heads at the springs (up to $65 \mathrm{kPa}$ at the natural ground level) are too small to create the fracture paths in the Triassic and Jurassic rocks needed to link the springs to the surface.

The pipes are interpreted here as collapse structures that were initiated in the Triassic and modified during subsequent periods of uplift during the Tertiary and Quaternary. In particular, the present structures largely result from collapse following the release of artesian water in the late Pleistocene when the fine-grained fraction of the infilling 
materials in the cavities in the Carboniferous Limestone was removed to produce unstable voids. When combined with the glacial and post-glacial history of the area, the recognition that the reservoirs for the hot springs are cavities at shallow depths $(<70 \mathrm{~m})$ in the Carboniferous Limestone explains why the hot springs are unique to one small area of Bath.

\section{Formation of the hot springs}

The suggested sequence of events that gave rise to the hot springs is summarised in Fig. 4. The precursor of the modern River Avon is thought to have been in place at the beginning of the last (Devensian) cold phase of the Pleistocene (Kellaway 1991c). The Bath area lay south of the ice sheets, but experienced alternations of periglacial and more temperate climates during the late Pleistocene (c125,000 to 10,000 years ago). During the cold phases, the presence of a permafrost layer up to $100 \mathrm{~m}$ thick, combined with rapid erosion and unloading, produced valley bulging in the Jurassic mudstones (Chandler et al. 1976) and caused fractures at shallow depths in the Carboniferous Limestone to open due to a combination of stress release and repeated freezing and thawing. Prior to that time, the irregularities in the Carboniferous Limestone surface would have had little or no effect on the local groundwater regime at Bath. Rapid changes in the local topography in the latest Pleistocene, particularly those in the postglacial phase (10,000 to 18,000 years ago) when the rate of downcuttting of the river is presumed to have been its greatest, brought the top of the Carboniferous Limestone sufficiently close to ground level at Bath to initiate a sequence of events that led to the formation of the hot springs.

The level of the valley floor in the latest Pleistocene would have been such that it was sufficiently close to warm water hosted in the Carboniferous Limestone knoll to melt a small area of permafrost. This allowed water to escape to the valley floor via fractures in the overlying Triassic and Jurassic rocks. Once these pathways had been established, the rate of groundwater flow increased as fine material was removed from the cavities in the limestone and, at some point, the overlying strata up to and including the river gravels collapsed to produce the spring pipes. Progressively warmer water was drawn from depth via deep fractures and the cavities in the Carboniferous Limestone as the flow rates increased. These flows may themselves have extended the cavities in the limestone to provide a more efficient transfer of heat to the near surface, as cave 
Gallois, R. W. 2007. The formation of the hot springs at Bath Spa, U.K. Geol. Mag. Vol. 144, 741-747.

systems do at the principal hot springs in Hungary (Muller \& Sáváry 1977). At Bath, the process continued until a new equilibrium state was reached in which the upward pressure of the artesian hot water was balanced against the frictional and gravitational pressures of the overburden materials.
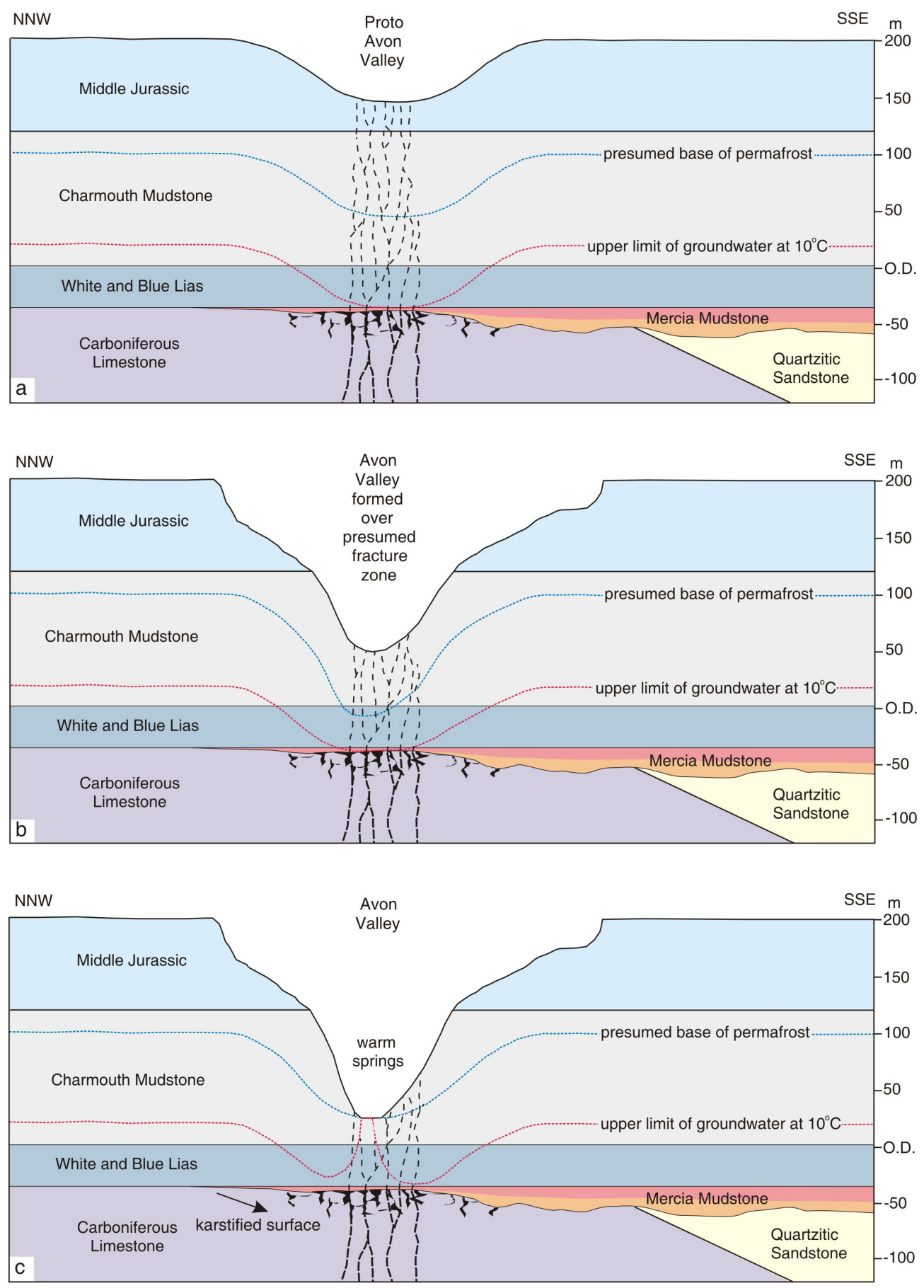

Figure 4. Sketch sections showing the suggested mechanism for the formation of the hot springs at Bath. 
(a) the precursor of the modern westward-flowing River Avon formed on a plateau of Jurassic limestones at c200 m O.D. during the last Pleistocene interglacial phase (Oxygen Isotope Stage $5 \mathrm{e}$ ), about 125,000 years ago. Sharp bends in the valley in the Bath area indicate the presence of fracture zones in the Jurassic and older rocks.

(b) rapid downcutting by gravel-laden meltwater torrents during the cold phases of the Devensian Stage (c 80,000 to 18,000 years ago) resulted in oversteepened valley sides with consequential cambering of the Middle Jurassic limestones, landslips and valley bulging in the Lower Jurassic mudstones, and fracture widening in the underlying rocks. During these cold phases, deep groundwater movement was confined by a layer of permafrost up to $100 \mathrm{~m}$ thick that sealed the valley floor and sides.

(c) continued lowering of the valley floor during the latest Pleistocene $(18,000$ to 10,000 years ago) allowed warm water hosted in the concealed Carboniferous Limestone to melt the permafrost seal and escape to the surface. The warm springs subsequently evolved to produce the present-day hot springs.

\section{Conclusions}

The ancestors of the modern thermal springs at Bath formed in the late Pleistocene as warm seepages that evolved into hot springs during the next few thousand years. This proposed mechanism for the formation of the hot springs explains their uniquely (in Britain) high temperature, and why they are confined to such a small area in the Avon Valley. There is no other known location in Britain where a river has rapidly removed most of a thick mudstone aquiclude that overlies at shallow depth a high point on a concealed palaeokarst limestone surface on the edge of a deep synclinal basin. The four other thermal springs in Britain are also hosted in the Carboniferous Limestone aquifer, but emerge at significantly lower temperatures. None has been linked to karst features other than joint widening and, most importantly, none is overlain by an aquiclude or aquitard that would prevent or inhibit mixing with cool near-surface waters.

The model proposed for the Bath hot springs has implications for their future protection. It suggests that the highly permeable collapse-debris in the spring pipes is underlain at shallow depth by an interlinked network of partially infilled solution pipes and/or cavities in the Carboniferous Limestone, and that the system is in a delicate state of balance. A small change in the temperature, pressure or flow rate at any one of the hot springs, whether natural or artificially induced, could have a marked affect on the whole system.

Acknowledgements. Almost all the pioneer work relating to the geology of the hot springs at Bath was carried out by Dr G. A. Kellaway, whose advice and encouragement is gratefully acknowledged. Mark Williams of Bath and North East Somerset Council is 
thanked for his assistance throughout this study and the Council for access to borehole data in its archive.

\section{References}

ANDREWS, J. N. 1991. Radioactivity and dissolved gases in the thermal waters of Bath. In Hot Springs of Bath (ed. G. A. Kellaway), pp. 157-170. Bath: Bath City Council. Andrews, J. N., Burgess, W. G., Edmunds, W. M., Kay, R. L. F. \& LeE, D. J. 1982. The thermal springs of Bath. Nature 298, 339-343

Baker, J. A., Downing, R. A., Gray, D. A., Findlay, J., Kellaway, G. A., Parker, R. H. \& Rollin, K. E. 2000. Hydrogeothermal studies in the United Kingdom. Quarterly Journal of Engineering Geology and Hydrogeology 33, 41-58.

Benton, M. J. \& Spencer, P. S. 1994. Fossil reptiles of Great Britain. Geological Conservation Review Series No. 10. London: Chapman and Hall, 400 pp.

Bevan T. G. \& HANCOCK P. L. 1986. A late Cenozoic regional mesofracture system in southern England and northern France. Journal of the Geological Society 143, 355-362. CAVE, R. C. 1977. The geology of the country around Malmesbury. Memoirs of the Geological Survey of Great Britain. London: HMSO, i-vii + 343 pp.

Chandler, J. R., Kellaway, G., Skempton, A. W. \& Wyatt, R. J. 1976. Valley slope sections in Jurassic strata near Bath. Philosophical Transactions of the Royal Society, A 283, 527-556.

Cunliffe, B. 1983. Earth's grip holds them. In Rome and her Northern Provinces (eds. B. Hartley and J. Weller), pp. 67-83. Gloucester: Allan Sutton.

DARLING W. G. \& EDMUNDS W. M. 2001. The hydrogeochemistry of waters from the Bath CSO Project investigation boreholes. British Geological Survey Technical Report $\mathrm{CR} / 01 / 126 \mathrm{C}, \mathrm{i}-\mathrm{ii}+12 \mathrm{pp}$.

DownInG, R. A. \& GRAY, D. A. 1986. Geothermal Energy - the potential in the United Kingdom. London: HMSO, i-xiii + 187 pp.

EDMUNDS, W. M. 2004. Bath thermal waters: 400 years in the history of geochemistry and hydrogeology. In 200 Years of British hydrogeology (ed. MATHER, J. D.), pp. 193199. Geological Society Special Publication No. 225. London: Geological Society.

EDMundS, W. M. \& MiLES, D. L. 1991. The geochemistry of Bath thermal waters. In Hot Springs of Bath (ed. G. A. Kellaway), pp. 143-156. Bath: Bath City Council. 
Edmunds, W. M., Darling, W. G., Purtschert, R. \& Corcho, J. 2002. The age and origin of the Bath thermal waters: new geochemical investigations as part of the Bath Spa Project. British Geological Survey Technical Report CR/01/263, i-iii + 19pp.

Hawkins, A. B. \& Kellaway, G. A. 1991. The hot springs of the Avon Gorge, Bristol, England. In Hot Springs of Bath (ed. G. A. Kellaway), pp. 179-204. Bath: Bath City Council.

Kellaway, G. A. 1991a. Investigation of the Bath hot springs (1977-1987). In Hot Springs of Bath (ed. G. A. Kellaway), pp. 97-126. Bath: Bath City Council.

Kellaway, G. A. 1991b. The work of William Smith at Bath (1799-1813). In Hot Springs of Bath (ed. G. A. Kellaway), pp. 25-54. Bath: Bath City Council.

Kellaway, G. A. 1991c. Thermal waters: structural and glacial control. In Hot Springs of Bath (ed. G. A. Kellaway), pp. 205-241. Bath: Bath City Council.

Kellaway, G. A. 1996. Discovery of the Avon-Solent Fracture Zone and its relationship to Bath hot springs. Environmental Geology 28, 34-39.

Kellaway, G. A. \& Welch, F. B. A. 1948. British Regional Geology: Bristol and Gloucester District, 2nd ed. London: HMSO, i-iv + 91 pp.

Kellaway, G. A. \& Welch, F. B. A. 1993. Geology of the Bristol district. Memoirs of the Geological Survey of Great Britain. London: HMSO, i-x + 199 pp.

McCann, C., Mann, A. C., McCann, D. \& Kellaway, G. A. 2002. Geophysical investigation of the thermal springs of Bath, England. In Sustainable Groundwater Development (eds. K. M. Hiscock, M. O. Rivett and R. M. Davison), pp. 15-40. Geological Society Special Publication no. 193. London: Geological Society. Muller, P. \& SÁVÁRY, I. 1977. Some aspects of developments in Hungarian speleology theories in the past ten years. Karszt-és barlang 12, 53-9.

RASTALL, R. H. 1926. On the geology of Bath springs. Geological Magazine 63, 98104.

SQuirrel, H. C. \& Downing, R. A. 1969. Geology of the South Wales Coalfield, Part 1. The country around Newport (Mon.). Memoirs of the Geological Survey of Great Britain. London: HMSO, i-xiii + 333 pp.

Stanton, W. I. 1991. Hydrogeology of the hot springs of Bath. In Hot Springs of Bath (ed. G. A. Kellaway), pp. 127-142. Bath: Bath City Council. WARNER, R. 1811. A new Guide through Bath and its Environs. Bath: Cruttwell, i-iv + $186 \mathrm{pp}$. 
Gallois, R. W. 2007. The formation of the hot springs at Bath Spa, U.K. Geol. Mag. Vol. 144, 741-747.

WHITE, D. E. 1957. Thermal waters of volcanic origin. Bulletin of the Geological Society of America 68, 1659-1682. 